\title{
GREEN BUILDINGS, ENVIRONMENTAL AWARENESS, AND ORGANIZATIONAL IMAGE
}

[Total word count without Abstract: 5,240]

\author{
Authors: \\ Mahbub Rashid, Ph.D., RA \\ Professor of Architecture \\ School of Architecture, Design and Planning \\ University of Kansas \\ 1465 Jayhawk Boulevard \\ Marvin Studios, Room 134 \\ Lawrence, KS 66045 \\ P: 785.864 .4405 \\ F: 785.864 .5185 \\ mrashid@ku.edu \\ Kent Spreckelmeyer, D.Arch., FAIA \\ Professor of Architecture \\ School of Architecture, Design and Planning \\ 415 Marvin Hall \\ 1465 Jayhawk Blvd. \\ The University of Kansas \\ Lawrence KS 66045 \\ P: 785.864 .3164 \\ F: 785.864 .5185 \\ kents@ku.edu \\ Neal J. Angrisano, AIA \\ Associate \\ Aviation \& Facilities Global Practice \\ Burns \& McDonnell \\ 9400 Ward Parkway \\ Kansas City, MO 64114 \\ P: 816.822 .3087 \\ F: 816.822 .3415 \\ nangrisano@burnsmcd.com
}




\title{
GREEN BUILDINGS, ENVIRONMENTAL AWARENESS, AND ORGANIZATIONAL IMAGE
}

\begin{abstract}
The paper reports a study that was conducted to understand the relationships between the occupants' assessments of the environmental design features of a "green" building and their assessments of environmental awareness (EA) and organizational image (OI). The study hypothesized that the occupant's assessments of individual workspace and departmental space features of a "green" building would directly affect their assessments of EA and OI, or that the occupant's assessments of individual workspace and departmental space features would indirectly affect their assessments of EA and OI through their satisfaction with individual workspace, departmental spaces and/or the building. In order to test these hypotheses, data were collected from 175 occupants of the Gold-level LEED-certified "green" building using a questionnaire instrument. Using frequency, correlational, and regression analyses of the data, the study found little or no evidence for direct relationships between the occupant's assessments of individual workspace and departmental space features and their assessments of EA and OI. The study, however, found some evidence for indirect relationships between the occupant's assessments of individual workspace and departmental space features and their assessment of EA and OI. The evidence showed that the occupant's assessments of individual workspace and departmental space features had affected their satisfaction with individual workspaces and the building, which then affected the occupants' assessments of EA and OI. The study is important for it provides evidence for connecting green buildings to organizational benefits and values.

Keywords: Green Buildings, Leadership in Energy and Environmental Design (LEED), Environmental Awareness, Organizational Image

Paper Classification: Research Paper
\end{abstract}




\section{INTRODUCTION}

For the purpose of this paper, any building with a Leadership in Energy and Environmental Design (LEED) certification from the US Green Building Council (USGBC) is considered a "green building." The USGBC's LEED rating system is a nationally accepted third party certification program for green building design, construction, and operation. The rating system promotes sustainability by recognizing performance in five key areas: sustainable site development, water savings, energy efficiency, materials selection, and indoor environmental quality (IEQ). It provides four levels of certification-basic certification, Silver, Gold, and Platinum-based on building performance measured using a set of prerequisites and credits in the five key areas listed above. Each higher level of certification represents an incremental step toward integrating the different components of sustainable design, construction, and operation to achieve optimal building performance. At present, the LEED rating system provides certifications for new construction and renovation, operations and maintenance of existing buildings, design of commercial interiors, building core and shell development, and neighborhood development and homes.

The USGBC and its LEED rating system have become hugely important for the US building industry in the context of global climate change and environmental sustainability. Buildings are one of the heaviest consumers of natural resources and account for a significant portion of the greenhouse gas emissions affecting climate change. In the US, buildings represent $38.9 \%$ of primary energy use, $38 \%$ of all $\mathrm{CO}_{2}$ emissions, and $72 \%$ of electricity consumption (EIA, 2008). Buildings also use $13.6 \%$ of all potable water, or 15 trillion gallons per year (USGS, 2000). Additionally, they use $40 \%$ of raw materials globally (3 billion tons annually) (Roodman et al., 1996). The Environmental Protection Agency (EPA) of the US Government estimates that 170 Million tons of building-related construction and demolition (C\&D) debris was generated in the US in 2003 , with $61 \%$ coming from nonresidential and $39 \%$ from residential source (US EPA, 2009).

In the US, the green building market was $2 \%$ of non-residential construction starts in $2005 ; 10-12 \%$ in 2008; and will grow to $20.25 \%$ by 2013 becoming a $\$ 96-140$ billion market (McGraw Hill Construction , 2009). As of October 2010, there were 19,101 commercial LEED registered projects, and 7,368 LEED certified projects. The cumulative square footage of all commercial LEED certified projects was over 1 billion and growing. Also as of October 2010, the USGBC had 80 local chapters, over 30,000 individual members, and 157,000 LEED credentialed professionals across all areas of practice (www.usgbc.org). The factors driving the green building market and its related professional developments in the US 
include government initiatives to reduce greenhouse gasses and energy consumption, heightened demand for green construction, and improvements in sustainable materials and technology (FMI, 2008).

\section{THE PROBLEM}

Despite the growing importance and interests, studies reported on the outcomes of LEED-certified green buildings are uneven. Many studies focus on cost related outcomes of these buildings suggesting that they save money. For example, in one report it is suggested that an upfront investment of $2 \%$ in green building design, on average, results in life cycle savings of $20 \%$ of the total construction costs - more than ten times the initial investment (Kats, 2003). In another, it is suggested that building sale prices for energy efficient buildings are as much as $10 \%$ higher per square foot than conventional buildings (Miller et al., 2007). Many other studies focus on resource and operational efficiency of green buildings suggesting that they consume less energy and fewer resources. For example, a post-occupancy evaluation of 12 General Services Administration (GSA) green buildings reports that in comparison to the average commercial building, these green buildings consume $26 \%$ less energy, have $13 \%$ lower maintenance costs, and have 33\% less greenhouse gas emissions (GSA PBS, 2008).

In contrast, fewer studies focus on individual benefits and values of green buildings. These studies in general suggest that the IEQ of green buildings are more conducive to individual performance, health, comfort and satisfaction than that of conventional buildings (Browning and Romm, 1995). That is because the prerequisites and credits for IEQ in the LEED rating system are among those that are already known to have positive effects on building occupants. For example, inclusion of high quality energy efficient lighting may reduce computer glare and increase visual comfort, increased use of day lighting may reduce energy demands and enhance interior lighting quality, certain construction practices may eliminate moisture build up and reduce mold growth, advanced ventilation and mechanical systems may increase air flow and reduce occupants' contact with airborne microbial agents, or design strategies that reduce sick building syndromes (SBS) may have positive effects on health and work performance. For a review of the related literature see (Rashid and Zimring, 2008).

Although outcomes related to cost, efficiency, and individual benefits and values are important, studies focusing on the potential connections between green buildings and organizational benefits and values are still missing. This is likely to be an important factor in the long-term market growth of green 
buildings, because organizational leaders who want to use green buildings to enhance organizational values and benefits do not yet have the necessary evidence they need to make their case. It is in this context, this paper studies the effects the environmental design features of green buildings on environmental awareness and organizational image.

\section{LINKING GREEN BUILDINGS TO ENVIRONMENTAL AWARENESS AND ORGANIZATIONAL IMAGE}

Buildings may be the most visible asset of an organization, but how may they affect organizational image (OI) is not well understood. More importantly, organizational image projected by buildings may also be linked to environmental awareness (EA). As early as 1993, in an extensive evaluation of companies is UK and Europe, Hodgkinson (1993) noted that businesses would increasingly want their flagship buildings to present an image of environmental friendliness in terms of energy efficiency, the use of building materials, and the impact on the wider environment. In a 1999 survey by BOMA International and the Urban Land Institute, $72 \%$ of building tenants maintained that it was important for their buildings to project an image of environmental friendliness (Baier, 1999). With increasing public awareness, commitment to environmental sustainability has become an important organizational asset. It is suggested in the literature that companies with the best environmental records would not only have a higher standing with the public, they would also develop more positive relationships with environmental regulators (Makower, 1994).

The benefits of green buildings in relation to EA and OI, however, are more likely to occur when buildings and organizations are treated as integrated systems. As Cole (1999) points out, when there is a lack of systems integration it is entirely possible to have a "green" building with "gray" occupants who do not have the appropriate knowledge to use the building. "Gray" occupants are also more likely to be found in buildings that "green" individual systems rather than the environment as a whole, or in buildings which focus primarily on technology and materials to the exclusion of social and psychological mechanisms at work in the organization. Further, it is possible to have "green" buildings occupied by "gray" organizations that pass up significant benefits offered by these buildings in terms of resource and operational efficiency, and human and organizational values. Therefore, to understand how the benefits of green buildings may accrue in relation to $\mathrm{EA}$ and $\mathrm{OI}$, it is necessary to begin with the occupants of green buildings. 
For this study, it is assumed that occupants' assessments of the "green" environmental features of a LEED-certified building may affect their assessments of EA and OI directly and/or indirectly [Figure 1]. In the direct way, the occupant's assessments of individual workspace and departmental space features of a LEED-certified building may affect how the occupants' assess EA and OI. In the indirect way, the occupant's assessments of individual workspace and departmental space features of a LEED-certified building may affect their satisfaction with individual and departmental spaces and with the building, which may then affect how the occupants' assess EA and OI.

\section{[Insert Figure 1 about here]}

More specifically, in the first part this study focuses on the following three questions to find out any direct effects of the occupant's assessments of environmental features on EA and OI:

1. Do the occupants of a LEED-certified green building assess various environmental features of the building favorably? If the occupants do not have a favorable view of these features, then it may be pointless to pursue the study any further.

2. Do the occupants of a LEED-certified green building agree that these buildings have positive effects on EA and OI? Despite having a favorable view of various environmental features if the occupants believe that the building does not positively affect EA and OI, then it is possible that the building uses "green" environmental features to the exclusion of some of the social and psychological mechanisms at work in the organization.

3. Finally, what is the relationship between the occupants' assessments of various environmental features of a LEED-certified green building and their assessments of EA and OI? This relationship may help us describe whether a green building is occupied by "gray" occupants or not. If there is no relationship between the occupants' assessments of the "green" environmental features and their assessments of EA and OI, then it is possible that that the benefits offered by the building are unknown to the occupants, something that can be observed among "gray" occupants.

In the second part, this study then focuses on the following three questions to find out any indirect effects of the occupant's assessments of environmental features on EA and OI via the occupants' satisfaction with individual workspaces, departmental spaces, and the building:

4. Are the occupants of a LEED-certified building generally satisfied with individual workspaces, departmental spaces, and the building? If the occupants are not satisfied with these spaces and/or the building but still assess various environmental features of these buildings favorably, 


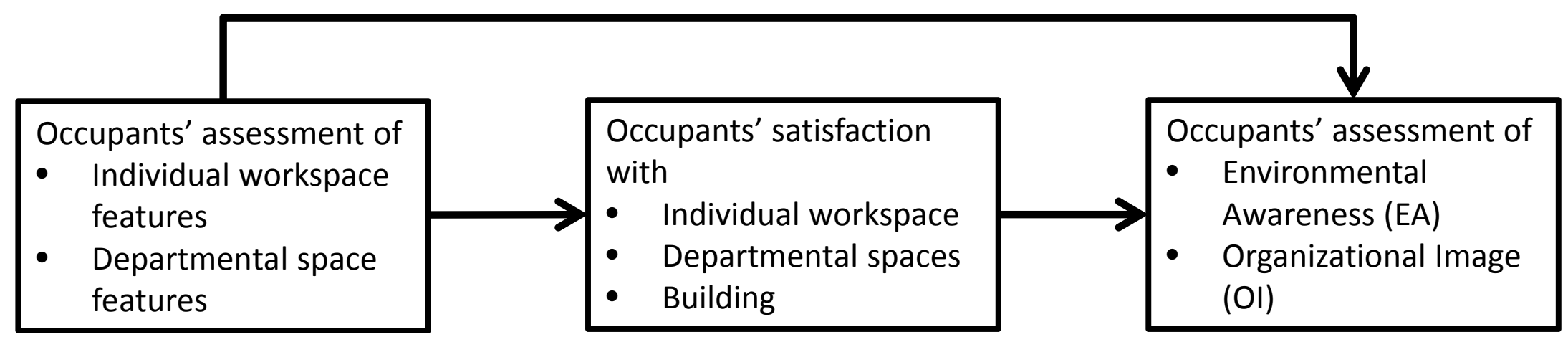

Figure 1: The study model 
then the occupants' satisfaction must depend on something else of the building and/or the organization. Likewise, if the occupants are not satisfied with these spaces and/or the building but still believe that the building has positive effects on EA and OI, then the occupants' assessments of EA and OI must depend on something else of the building and/or the organization.

5. If the occupants of a LEED-certified building are generally satisfied with individual workspaces, departmental spaces and the building, then what is the relationship between the occupants' assessments of various environmental features of a LEED-certified green building and their satisfaction?

6. Finally, if the occupants of a LEED-certified building are generally satisfied with individual workspaces, departmental spaces, and the building, then what is the relationship between the occupants' satisfaction and their assessments of EA and OI?

\section{THE CASE STUDY}

The study was conducted at a Gold-level LEED-certified public office building. Figures 2-9 show the office building and a few selected spaces within the building. Environmental highlights of the building in the five key areas of the LEED rating systems include the following:

Water. The building uses bio-swales to clean parking lot run-off, and bio-filter in the lobby to clean rain water from roof. It also uses native or adapted grass and plant species to reduce water consumption. Its site irrigation system is rain fed. The building includes grey water recycling system for toilet flushing, low-flow and hands free faucets and fixtures, and waterless urinals.

Energy. The building uses highly efficient mechanical systems, and floor plenum displacement ventilation. It also uses sophisticated building automation system. The building includes significant amount of day lighting, and high efficiency indirect computer controlled lighting to reduce the need for artificial lighting. It was also designed for $45 \%$ energy use reduction below a code minimum building.

Site. The building was designed to reduce site disturbances. It preserved existing trees and habitats. The building has full cut-off lighting fixtures to help minimize light pollution in and around the site. 
Materials. The building diverted $90 \%$ of construction waste. $20 \%$ of all materials used in the building were manufactured within 500 mile radius of site. It used reclaimed cedar from demolished building. It also used recycled glass chips for terrazzo floor, and high recycled-content steel structure, carpet fiber and other materials. Further, it used corn based fabrics.

Indoor Environmental Quality (IEQ). The building uses sustainable materials and furniture with offgassing volatile organic compounds (VOCs). It has systems of containment for source pollutants. It also provide high amount of fresh air intake. Each individual office space has HVAC control. Private offices are placed inside and workstations are placed around the perimeter. As a result, more workers have access to natural light and outside view. Office workers also share several amenities including a huge well-lit atrium, well-lit corridors with invitingly warm woodwork, technology-enhanced conference spaces with outdoor views, and improved service areas. The building also has a system of green housekeeping in place.

Recognitions received in addition to the Gold-level LEED certification. The building received the 2005 Achievement Award for making the design-build Process work for County Government by the National Association of Counties, the 2005 Public Technology Institute Award, the 2006 Excellence Award by the Design-Build Institute of America, the 2006 Merit Award for Excellence in Architecture by Kansas Chapter of the AIA, the 2006 Excellence Award by the Mid-America Chapter of the Design-Build Institute of America, the 2006 Award for Merit by Kansas City AIA Committee on the Environment, the 2007 KC Business Journal Capstone Award, the 2007 Construction Specifications Institute (CSI) Environmental Stewardship Award, the 2007 Achievement Award for setting a new standard for public capital investment by the National Association of Counties, the 2007 EPA Blue Skyways Partnership Award, and the 2007 Bridging the Gap Environmental Excellence award for Business.

[Insert Figures 2-9 about here]

\section{METHODS}

Data collection methods. Data for the study were collected via an anonymous questionnaire survey. Institutional Review Board (IRB) approval for the survey was obtained from the Human Subjects Committee of the involved institution. The IRB-required information and cover sheets were attached to 


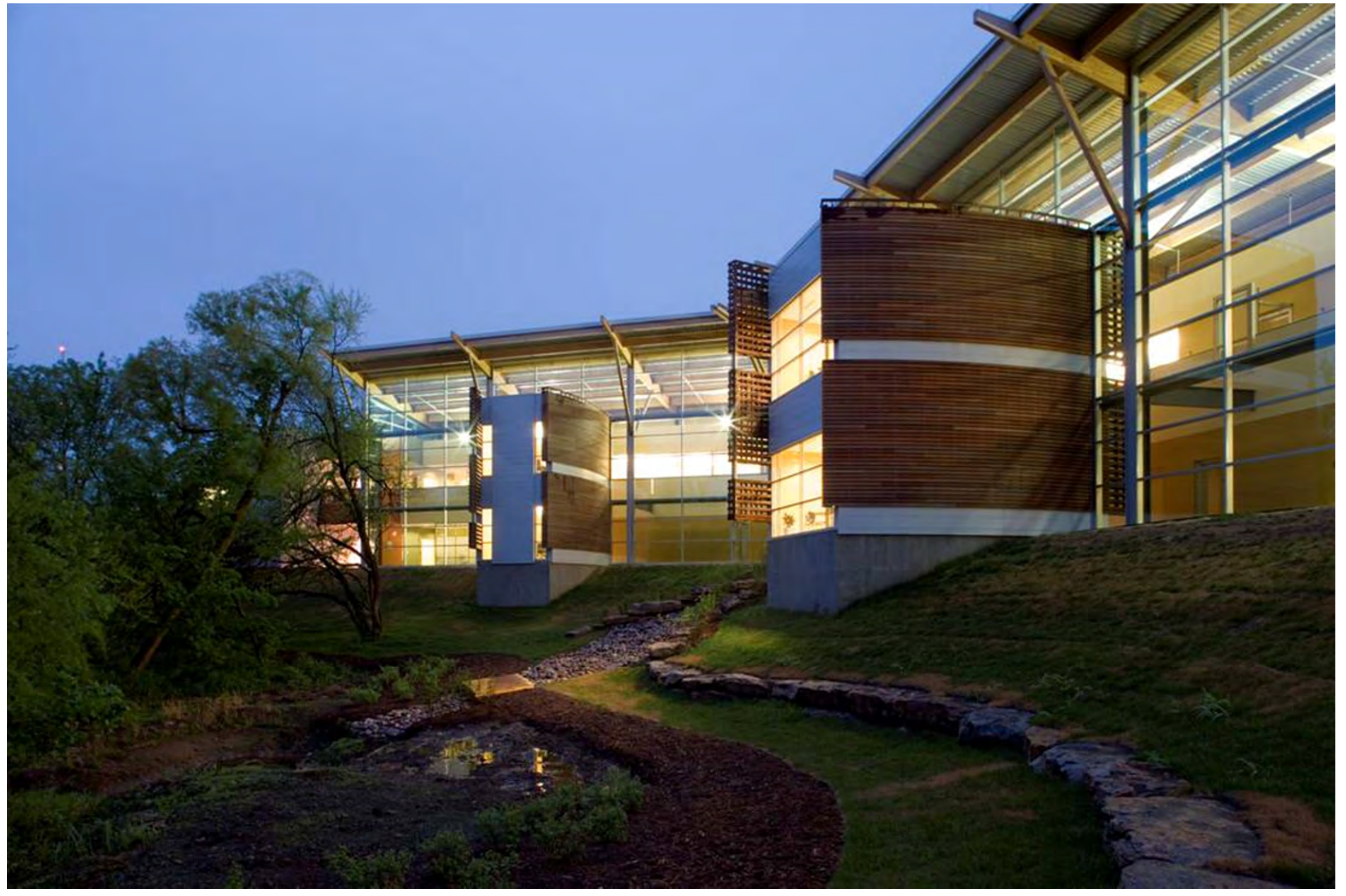

Figure 2: A view of the building showing bio-swales, trees, and habitats. 


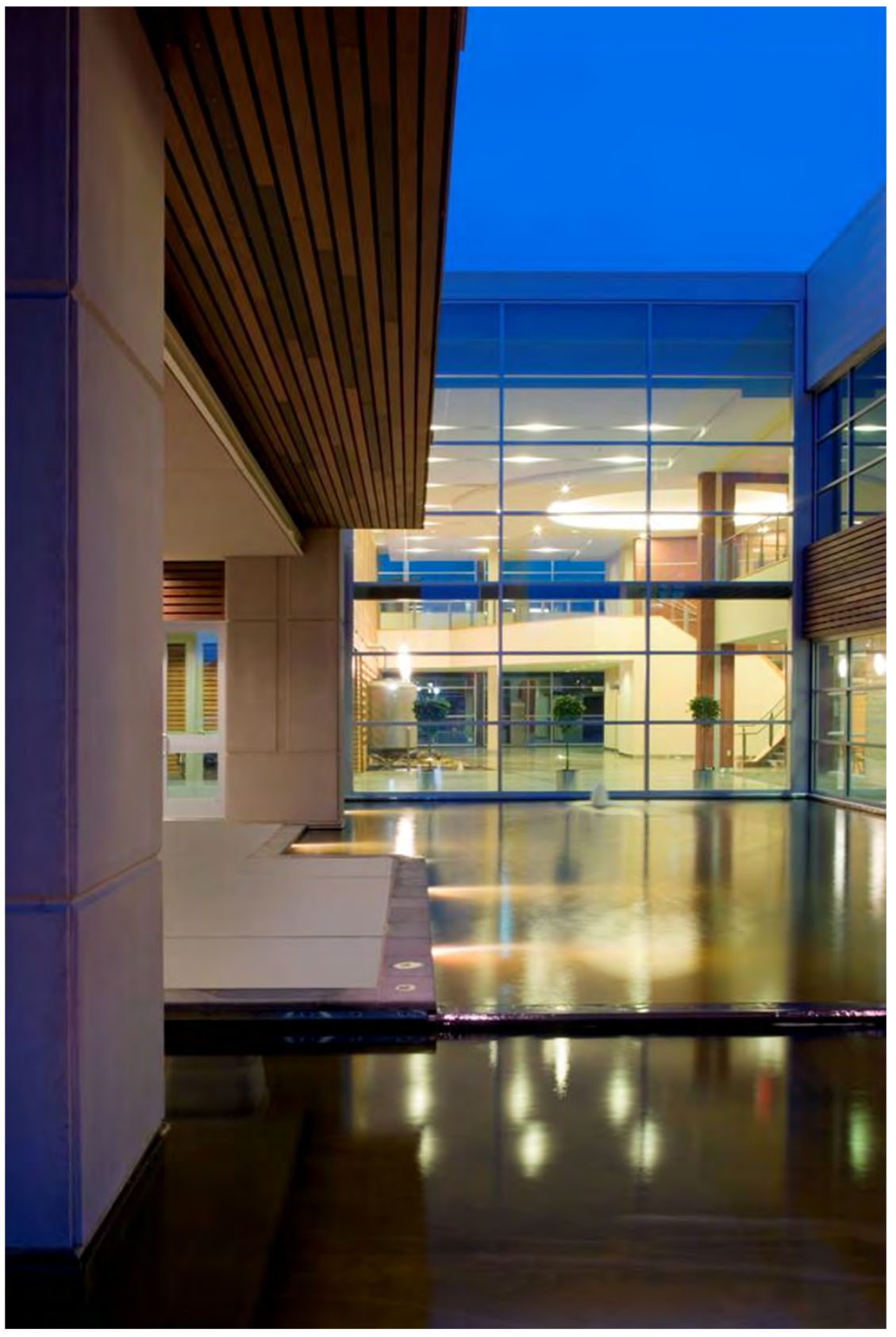

Figure 3: The reflecting pool at the entrance of the building works as a retention pond.

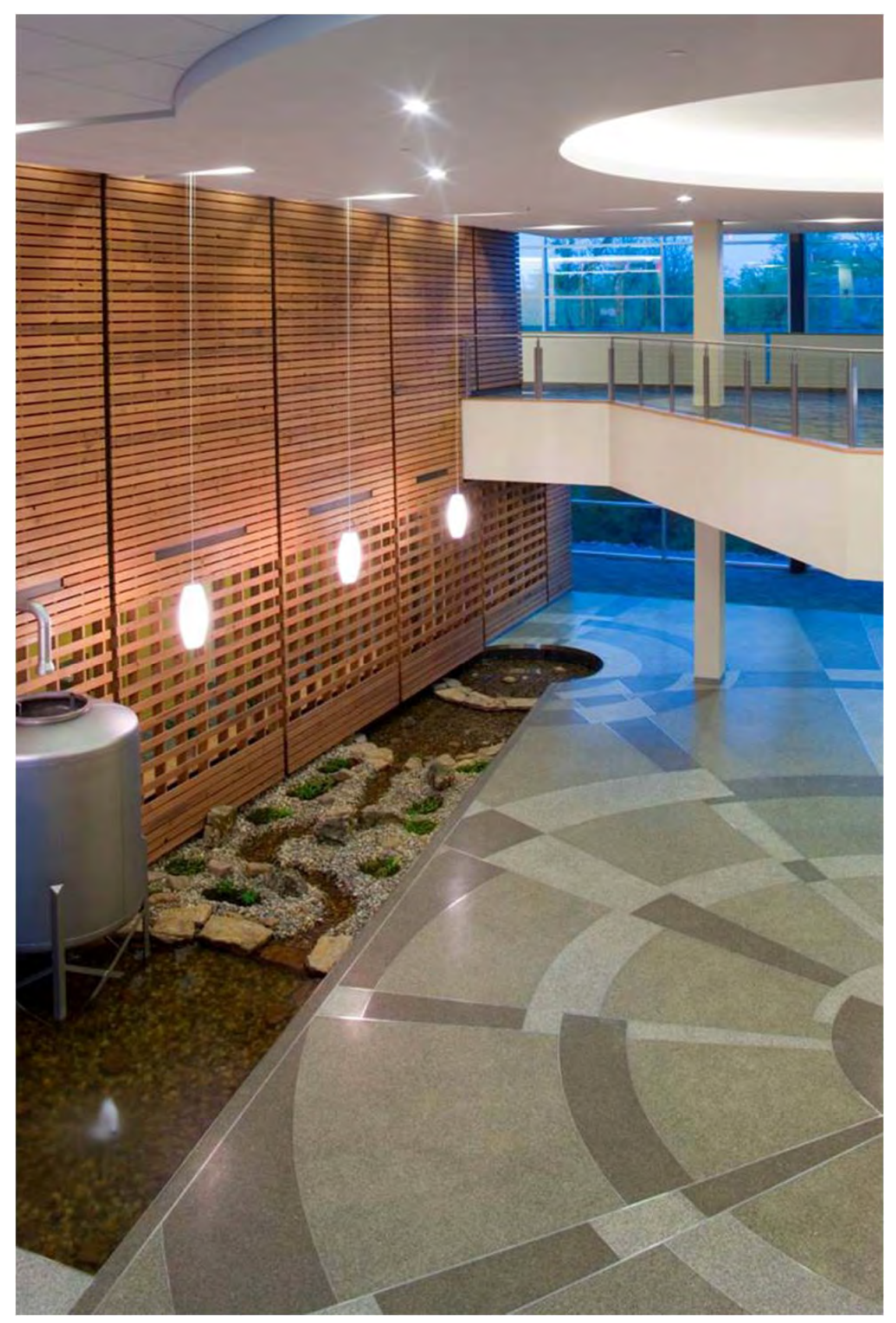

Figure 4: The bio-filter in the lobby of the building helps clean rain water from the roof 


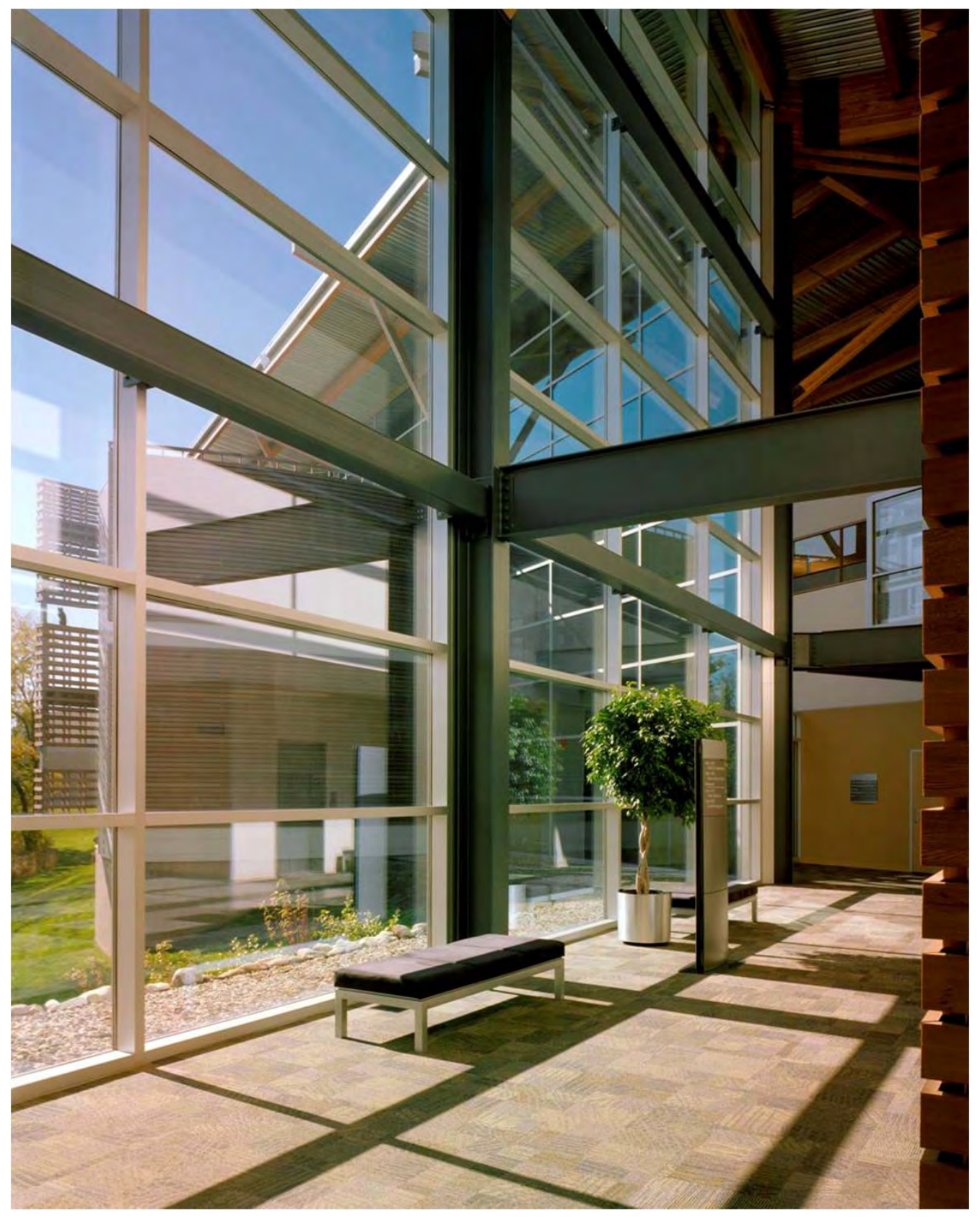

Figure 5: Ample natural light reduces the need for artificial lighting in the building. 


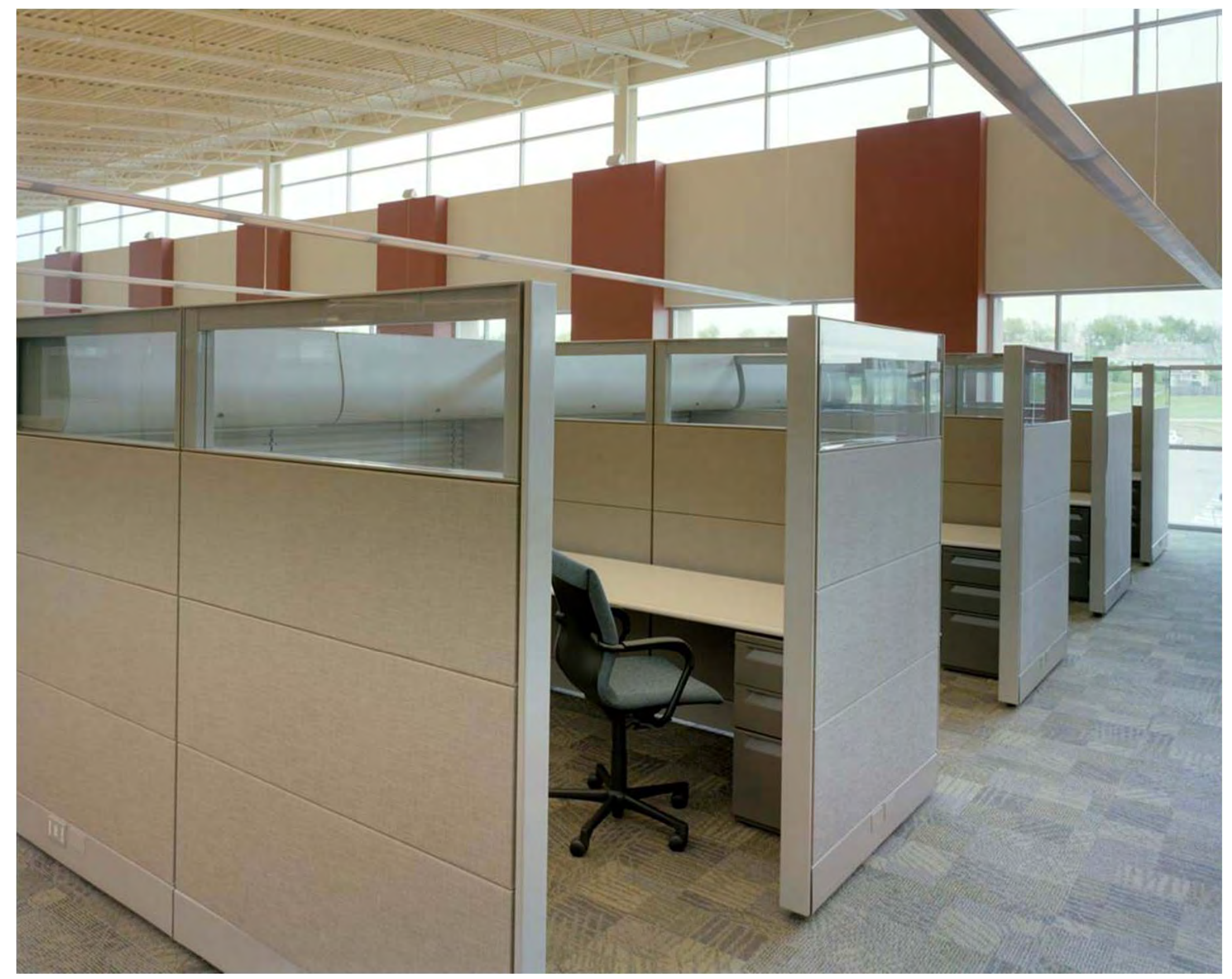

Figure 6: Each workstation in the building has ample natural light and easy access to natural view. 


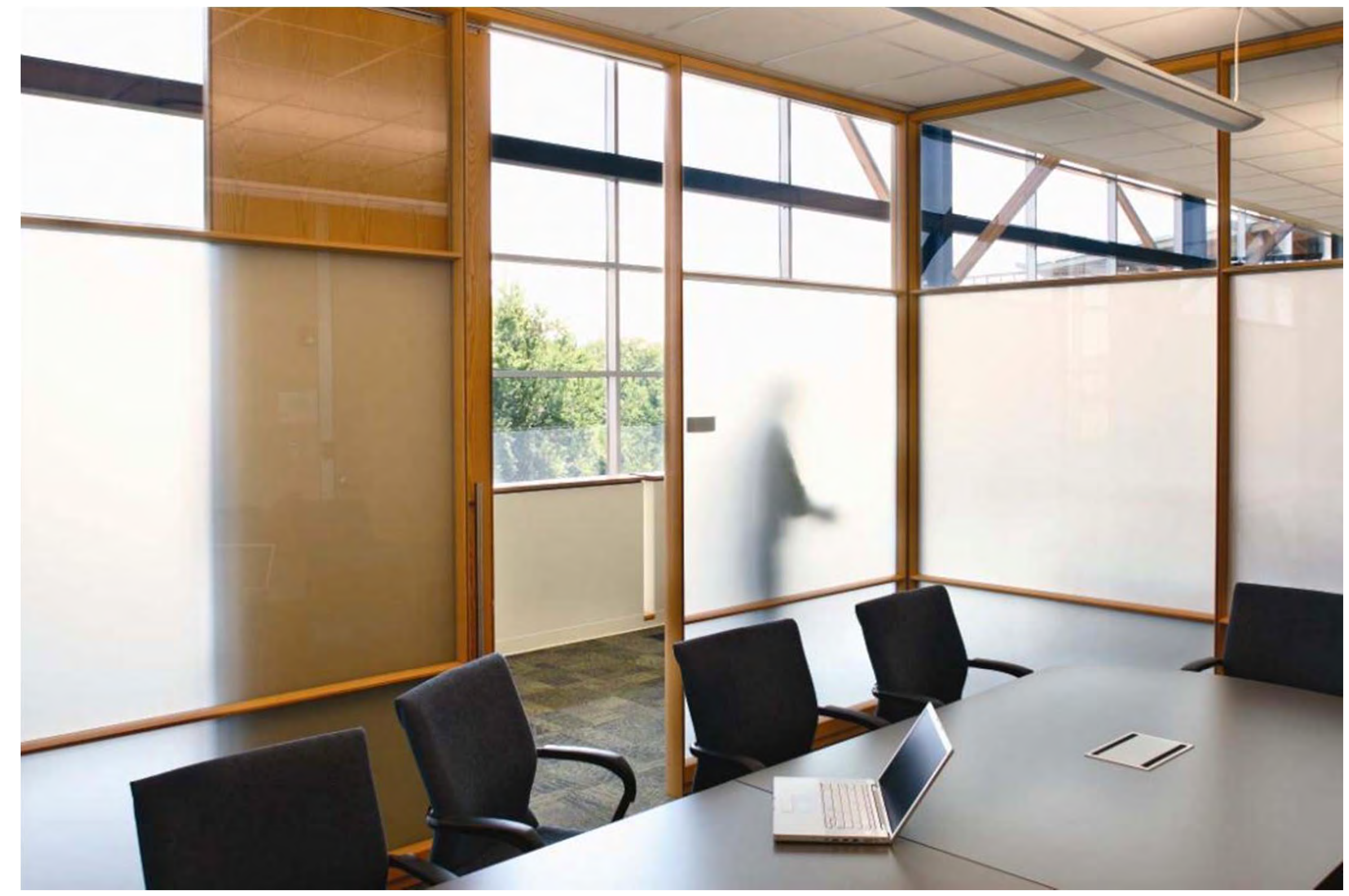

Figure 7: Technology-enhanced conference spaces also have natural light and views. 


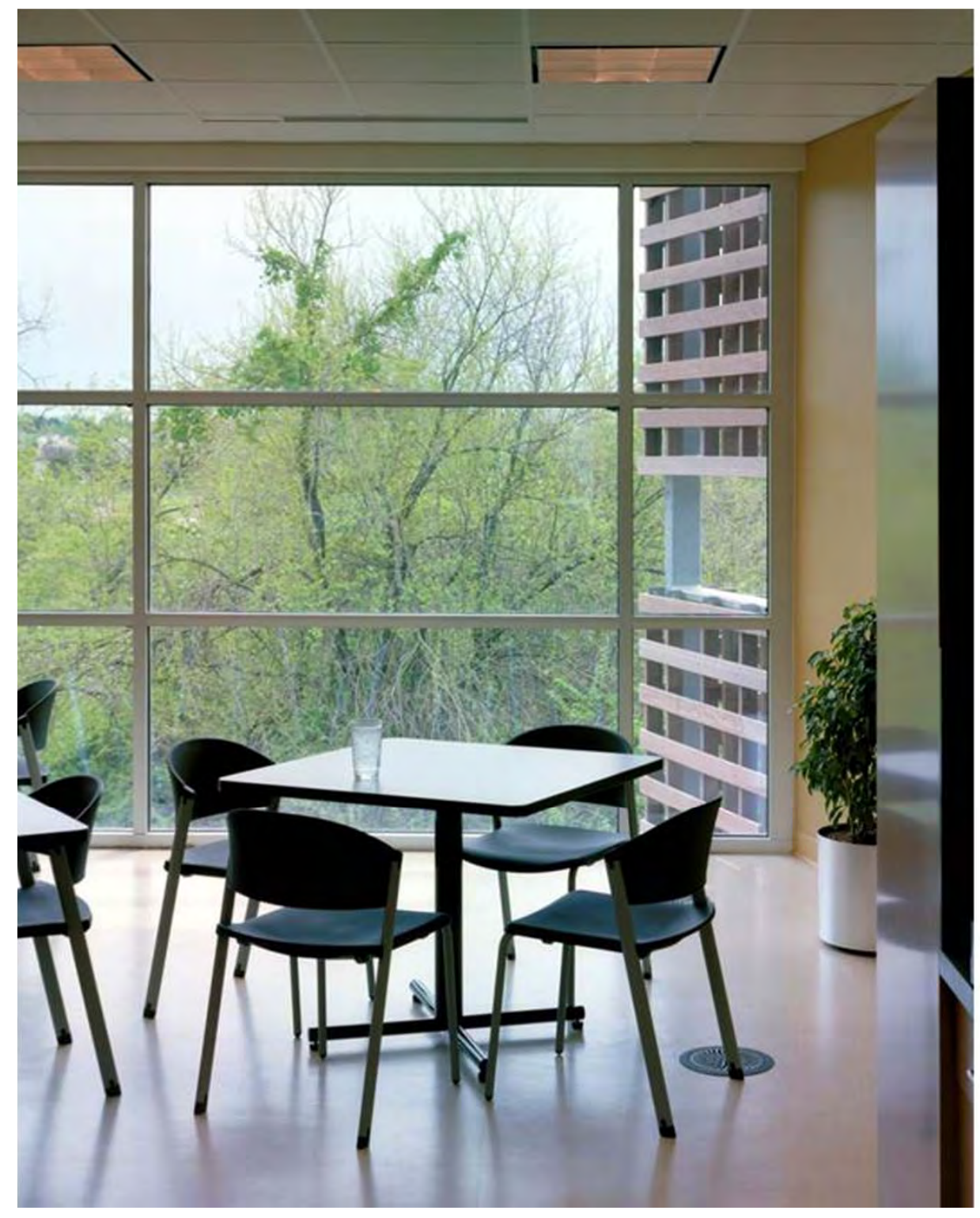

Figure 8: A view of a lounge area.

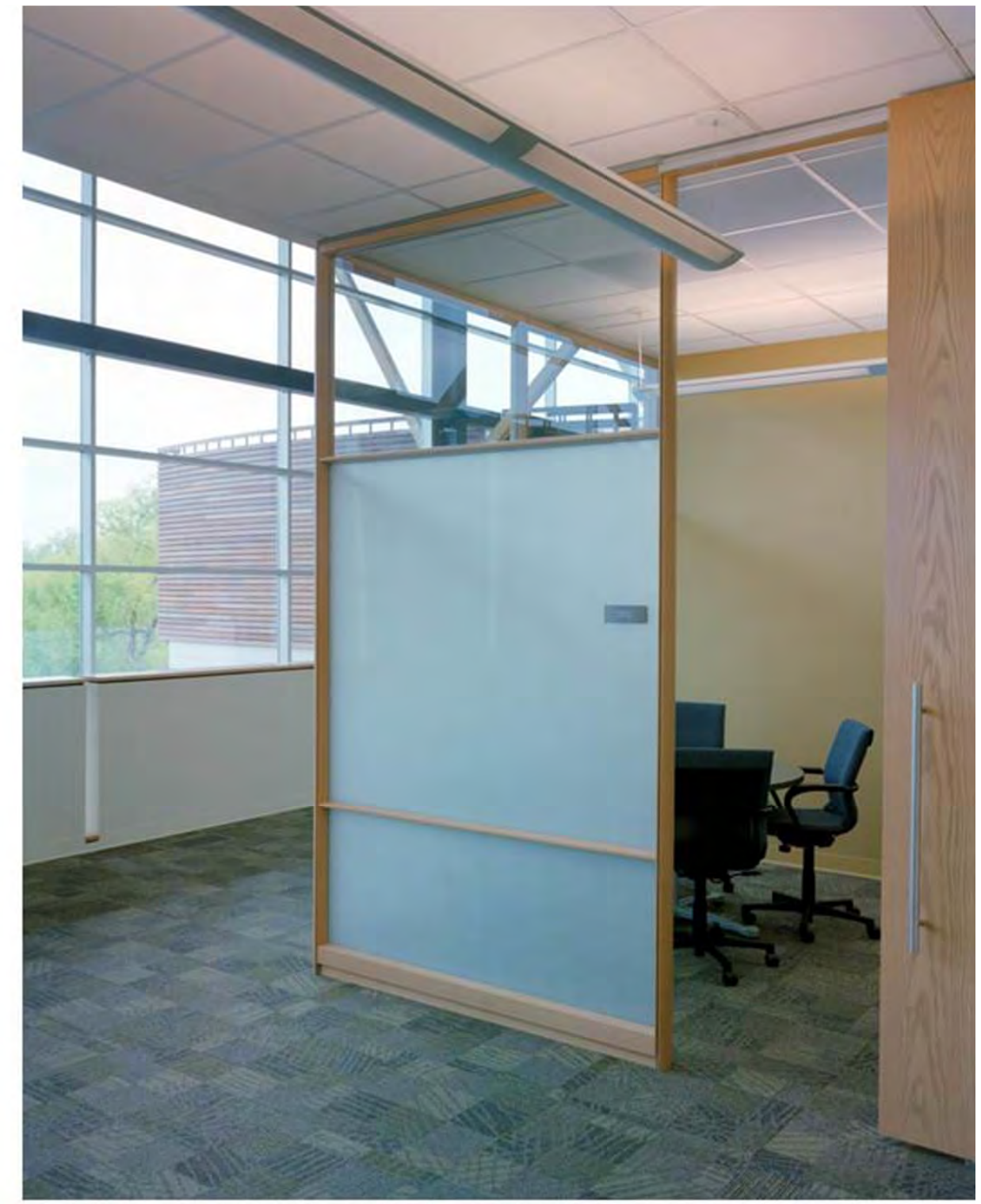

Figure 9: A view of a group meeting space. 
the questionnaire to ensure that participating office workers fully understood the intent of the study and the consequences of their participation. The purpose and methods of the survey were discussed with office managers, who then described these to office workers. Participation in the study was voluntary. On the day of survey, research representatives left the questionnaire on each office worker's desk. Office workers could complete the questionnaire any time during a period of one week after they received the questionnaire. The respondent put the filled-out questionnaire in a sealed envelope and returned it to boxes kept at predetermined locations within the building.

The questionnaire. The questionnaire was developed for a much larger study of office workers (References omitted for peer review). Among the many questions included in the questionnaire, this study utilized only some of those related to individual background, workplace design, and individual and organizational outcomes. Questions on individual background included gender, job type and age group. Questions on workplace design included some on environmental features of individual workspaces, and others on departmental spaces or common amenities [Table 1]. They also included questions on satisfaction with workspaces, departmental spaces and the building. Among the many questions on organizational outcomes, some were regrouped to create two multi-item scales describing organizational image and environmental awareness [Table 2]. The questionnaire utilized a five-point bipolar scale to score responses against each question related to environmental features, satisfaction, and organizational outcomes.

[Insert Tables $1 \& 2$ about here]

Data analysis methods. Altogether, the building had 284 office workers at the time of the survey. There were 175 appropriately filled out questionnaires (response rate: 61.6\%). The numbers of valid returns by gender, job type, and age group are given in Table 3. Questionnaire data were manually entered into an SPSS (SPSS Inc., Chicago, IL) database. Standard data checking and verification were performed (e.g., range, distribution, pattern of missing values). Factor analyses of the two scales - EA and OI-extracted one primary component for each, therefore no item was eliminated. Reliability analyses showed the scales to have acceptable Cronbach's alpha values [Table 2].

The following analyses were completed to find out the answers to the six study questions posed earlier:

1. For the first question, frequencies of the responses on the questions related to individual workspace and departmental space features were analyzed. 


\begin{tabular}{|c|c|}
\hline Workspace related questions & Departmental space related questions \\
\hline amount of area in personal workspace fits needs & can socialize in corridors/circulation areas \\
\hline sufficient work surfaces in workspace & can socialize in lounge/break room \\
\hline enough storage in workspace & can socialize in coffee/snack bar \\
\hline furniture in workspace is sufficient & building provides opportunities for informal conversation \\
\hline can enjoy outside view & people I need to work with are close to my work area \\
\hline can adjust workspace for needs & shared spaces for teamwork/impromptu meetings \\
\hline workspace helps accomplishing tasks & have no difficulty finding people needed to get work done \\
\hline have enough privacy & can choose where I get work done in bldg. \\
\hline can adjust workspace to increase privacy & have easy access to equipment \\
\hline conversations with co-workers cannot be overheard & do not have to go out of way to get info from co-workers \\
\hline phone conversations cannot be overheard & support equipment is convenient to workspace \\
\hline have enough privacy to do job well & layout of departmental workspace supports teamwork \\
\hline have enough natural light in workspace & layout of department supports impromptu meetings \\
\hline workspace is not too bright & office does not lack informal meeting spaces \\
\hline lighting at desk helps job & conference and/or training rooms support tasks \\
\hline have enough fresh air in workspace & conference spaces available when needed \\
\hline happy with air quality & conference spaces have suitable sizes \\
\hline not too hot in workspace & office spaces are flexible \\
\hline \multicolumn{2}{|l|}{ not too cold in workspace } \\
\hline air not too dry in workspace & \\
\hline
\end{tabular}

Table 1: Individual workspace and departmental space related questions 


\begin{tabular}{|c|c|c|c|}
\hline Scales & Items & $\begin{array}{l}\text { Factor Analysis } \\
\text { Extraction Method: } \\
\text { Principal Component } \\
\text { Analysis }\end{array}$ & $\begin{array}{l}\text { Cronbach's } \\
\text { Alpha }\end{array}$ \\
\hline $\begin{array}{l}\text { Organizational } \\
\text { Image }\end{array}$ & $\begin{array}{l}\text { 1. public image improved since we relocated in this building } \\
\text { 2. organization hires better people since we relocated in this building } \\
\text { 3. having a job in this building carries a positive image } \\
\text { 4. employees respect job more since we relocated in this building } \\
\text { 5. respect my job more since we relocated in this building } \\
\text { 6. this building affects my desire to stay with the organization }\end{array}$ & $\begin{array}{l}\text { One primary component } \\
\text { was extracted }\end{array}$ & 0.884 \\
\hline $\begin{array}{l}\text { Environmental } \\
\text { Awareness }\end{array}$ & $\begin{array}{l}\text { 1. this building has a positive effect on the environment } \\
\text { 2. our reputation as an environment conscious org improved since we } \\
\text { relocated } \\
\text { 3. employees care more about environment since we relocated in this } \\
\text { building } \\
\text { 4. I care more about environment since we relocated in this building } \\
\text { 5. employees believe all buildings should be designed like this building } \\
\text { 6. I believe all buildings should be designed like this building } \\
\text { 7. this building helps conserve energy } \\
\text { 8. this building provides healthy work environment }\end{array}$ & $\begin{array}{l}\text { One primary component } \\
\text { was extracted }\end{array}$ & 0.899 \\
\hline
\end{tabular}

Table 2: Items in the organizational image and environmental awareness scales and their Cronbach's Alpha values 


\begin{tabular}{|l|l|l|l|l|l|l|l|l|l|l|l|l|l|l|l|}
\hline \multicolumn{2}{|l|}{ Total Number of participants = 175} \\
\hline
\end{tabular}

SM: Senior Manager. MM: Mid-level Manager. P: Professionals. S: Staff

Table 3: Valid returns by gender, job type, and age group 
2. For the second question, frequencies of the responses on the EA and OI scales were analyzed. These responses were then broken down according to gender, job type, and age group to find out if these categories had any differential effects on the occupants' assessments of EA and OI.

3. For the third question, correlational analyses between the occupants' assessments of workplace environmental design features and their assessments of EA and OI were performed; and regression models were developed with the occupants' assessments of workplace environmental design features as the predictor variables and their assessments of EA and OI as the dependent variables.

4. For the fourth question, frequencies of the responses on the questions related to satisfaction with individual workspaces, departmental spaces and the building were analyzed.

5. For the fifth question, regression models were developed with the occupants' assessments of workplace environmental variables as the predictor variables and their satisfaction with individual workspaces, departmental spaces and the building as the dependent variables.

6. Finally, for the sixth question, regression models were developed with the occupants' satisfaction with individual workspaces, departmental spaces and the building as the predictor variables and their assessments of EA and $\mathrm{OI}$ as the dependent variables.

\section{RESULTS}

Table 4 \& Figure10 show the results of the analysis of the frequencies of the occupants' assessments of workspace features. More occupants agreed than disagreed with the following workspace features: (1) amount of area in personal workspace fits needs, (2) have sufficient work surfaces in workspace, (3) have enough storage in workspace, (4) furniture in workspace is sufficient, (5) can enjoy outside view, (6) can adjust workspace for needs, (7) workspace helps accomplishing tasks, (8) have enough natural light in workspace, (9) workspace is not too bright, (10) lighting at desk helps job, (11) have enough fresh air in workspace, (12) happy with air quality, (13) not too hot in workspace, (14) not too cold in workspace, (15) air not too dry in workspace, and (16) satisfied with workspace. In contrast, more occupants disagreed than agreed with the following workspace features: (1) have enough privacy, (2) can adjust workspace to increase privacy, (3) conversations with co-workers cannot be overheard, (4) phone conversations cannot be overheard, and (5) have enough privacy to do job well. 


\begin{tabular}{|c|c|c|c|}
\hline & Disagree (\%) & Neutral (\%) & Agree (\%) \\
\hline amount of area in personal workspace fits needs & 22.9 & 7.8 & 69.3 \\
\hline sufficient work surfaces in workspace & 41.3 & 11.7 & 47 \\
\hline enough storage in workspace & 29.6 & 18.4 & 52 \\
\hline furniture in workspace is sufficient & 13.4 & 16.2 & 70.4 \\
\hline can enjoy outside view & 24.3 & 37.9 & 37.8 \\
\hline can adjust workspace for needs & 31.8 & 24.6 & 43.6 \\
\hline workspace helps accomplishing tasks & 26.8 & 18.4 & 54.8 \\
\hline have enough privacy & 62 & 19 & 19 \\
\hline can adjust workspace to increase privacy & 82.7 & 8.9 & 8.4 \\
\hline conversations with co-workers cannot be overheard & 88.8 & 6.7 & 4.5 \\
\hline phone conversations cannot be overheard & 89.4 & 6.1 & 4.5 \\
\hline have enough privacy to do job well & 43.6 & 26.3 & 30.1 \\
\hline have enough natural light in workspace & 36.9 & 20.7 & 42.4 \\
\hline workspace is not too bright & 10.1 & 17.3 & 72.6 \\
\hline lighting at desk helps job & 17.3 & 24.6 & 58.1 \\
\hline have enough fresh air in workspace & 29.1 & 28.5 & 42.4 \\
\hline happy with air quality & 21.2 & 33 & 45.8 \\
\hline not too hot in workspace & 29.1 & 21.8 & 49.1 \\
\hline not too cold in workspace & 34.1 & 20.7 & 45.2 \\
\hline air not too dry in workspace & 22.9 & 45.8 & 31.3 \\
\hline
\end{tabular}

Table 4: Occupants' responses to individual workspace related questions 


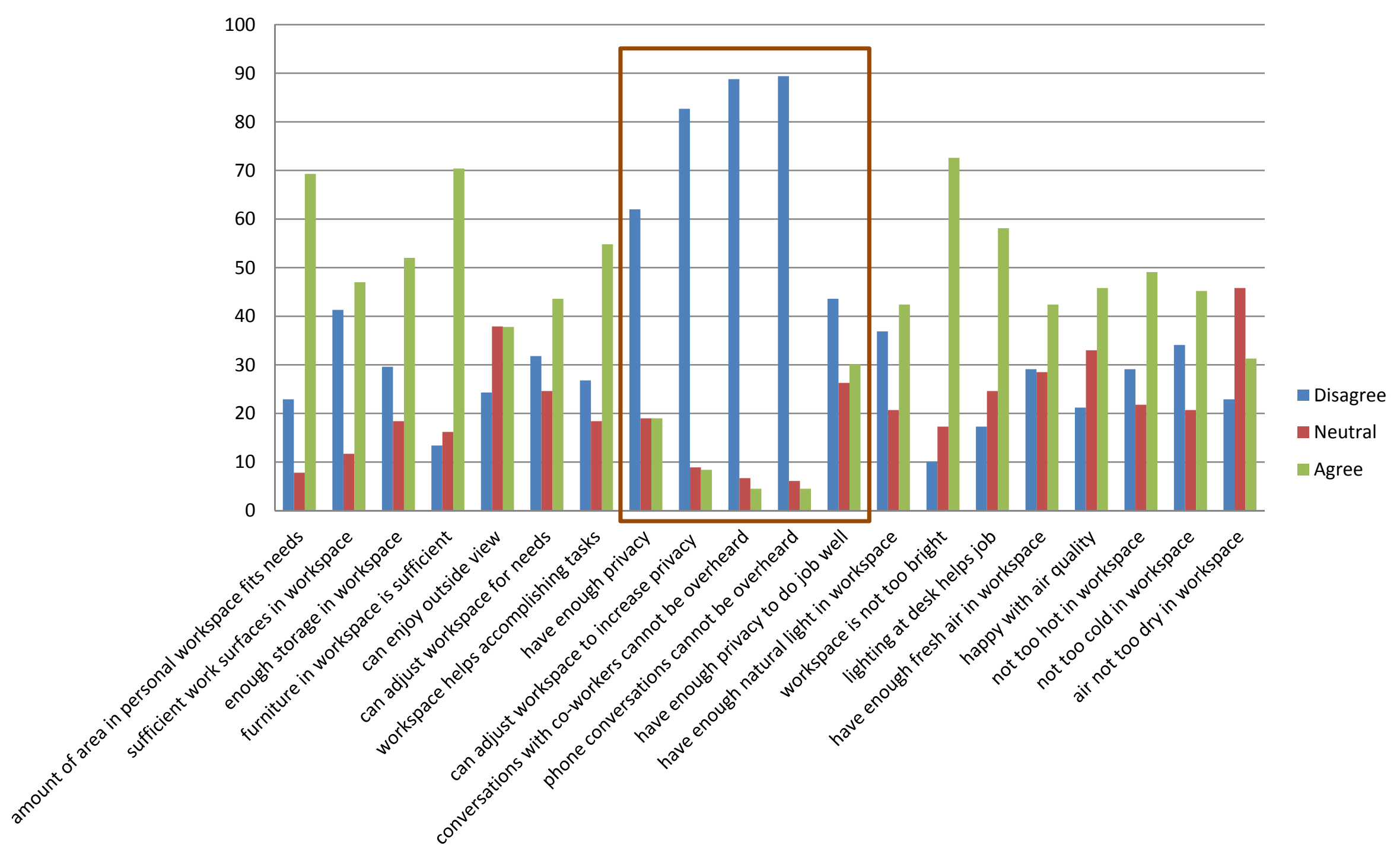

Figure 10: Occupants' responses to individual workspace related questions 
[Insert Table 4 \& Figure10 about here]

Table 5 \& Figure11 show the results of the analysis of the frequencies of the occupants' assessments of departmental space features. More occupants agreed than disagreed with the following departmental space features: (1) can socialize in corridors/circulation areas, (2) can socialize in lounge/break room, (3) can socialize in coffee/snack bar, (4) building provides opportunities for informal conversation, (5) people I need to work with are close to my work area, (6) have shared spaces for teamwork/impromptu meetings, (7) have no difficulty finding people needed to get work done, (8) have easy access to equipment, (9) do not have to go out of way to get info from co-workers, (10) support equipment is convenient to workspace, (11) layout of departmental workspace supports teamwork, (12) layout of department supports impromptu meetings, (13) office does not lack informal meeting spaces, (14) conference and/or training rooms support tasks, (15) conference spaces available when needed, (16) conference spaces have suitable sizes, (17) office spaces in the department are flexible, (18) satisfied with location of workspaces in the department, and (19) satisfied with the layout of department. In contrast, more occupants disagreed than agreed with the following departmental space feature: (1) can choose where I get my work done in bldg.

[Insert Table 5 \& Figure11 about here]

Tables $6,7 \& 8$ and Figures $12,13 \& 14$ show the results of the analysis of the frequencies of the occupants' assessments of EA and OI. More occupants agreed than disagreed that the building helped improve their EA. In contrast, more occupants disagreed than agreed that the building helped improve their OI. These findings do not change for gender, job type, and age group except for the over 60 age group. For this age group, the percentage of occupants who agreed that the building helped improve their EA and OI was equal to the percentage of occupants who disagreed that the building helped improve their EA and OI.

[Insert Tables 6, $7 \& 8$ and Figures 12, 13 \&14 about here]

Tables 9-11 show the results of the correlational and regression analysis studying the relationships between the occupants' assessments of individual workspace and departmental space features and that of EA and OI. The occupants' assessments of most individual workspace features showed significant correlation with that of EA and OI [Table 9]. However, a regression analysis with Ol as the dependent variable and workspace features showing significant correlations as the predictor variables returned no 


\begin{tabular}{|c|c|c|c|}
\hline & Disagree (\%) & Neutral (\%) & Agree (\%) \\
\hline can socialize in corridors/circulation areas & 15.9 & 17.6 & 66.5 \\
\hline can socialize in lounge/break room & 21.3 & 25.3 & 53.4 \\
\hline can socialize in coffee/snack bar & 20.3 & 27.9 & 51.8 \\
\hline building provides opportunities for informal conversation & 17 & 19.3 & 63.7 \\
\hline people I need to work with are close to my work area & 15.3 & 9.7 & 75 \\
\hline shared spaces for teamwork/impromptu meetings & 14.2 & 13.1 & 72.7 \\
\hline have no difficulty finding people needed to get work done & 25.6 & 18.8 & 55.6 \\
\hline can choose where I get work done in bldg. & 65.3 & 19.9 & 14.8 \\
\hline have easy access to equipment & 5.7 & 10.2 & 84.1 \\
\hline do not have to go out of way to get info from co-workers & 26.1 & 18.8 & 55.1 \\
\hline support equipment is convenient to workspace & 27.3 & 11.9 & 60.8 \\
\hline layout of departmental workspace supports teamwork & 29 & 21 & 50 \\
\hline layout of department supports impromptu meetings & 30.7 & 25 & 44.3 \\
\hline office does not lack informal meeting spaces & 26.1 & 22.7 & 51.2 \\
\hline conference and/or training rooms support tasks & 15.9 & 21.6 & 62.5 \\
\hline conference spaces available when needed & 22.2 & 32.4 & 45.4 \\
\hline conference spaces have suitable sizes & 25 & 23.3 & 51.7 \\
\hline office spaces are flexible & 25.6 & 30.1 & 44.3 \\
\hline
\end{tabular}

Table 5: Occupants' responses to departmental space related questions 


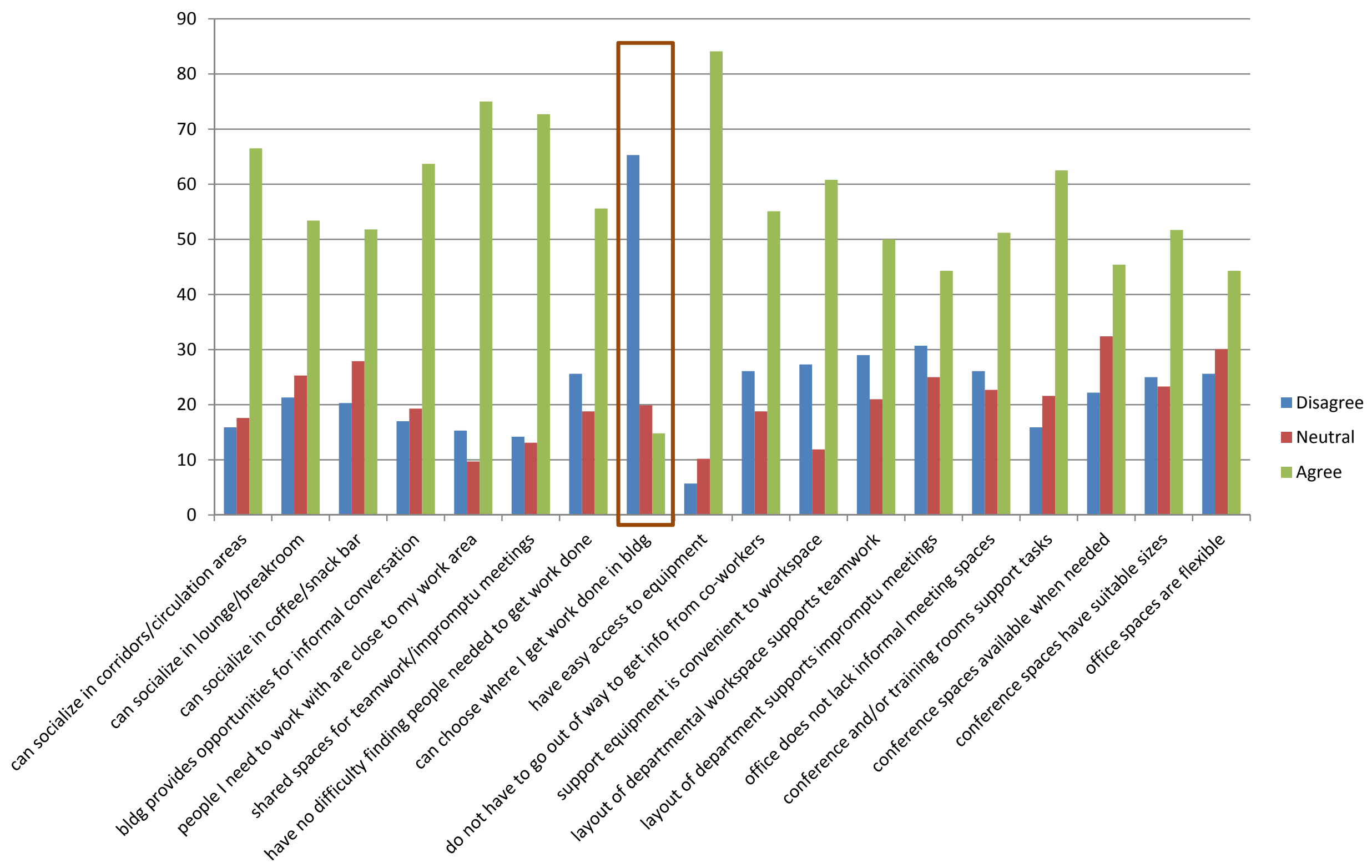

Figure 11: Occupants' responses to departmental space related questions 


\begin{tabular}{|l|l|l|l|l|l|l|l|l|l|}
\hline & \multicolumn{2}{|l}{ Disagreed (\%) } & \multicolumn{2}{l|}{ Neutral (\%) } & \multicolumn{2}{l|}{ Agreed (\%) } \\
\hline & All & Male & Female & All & Male & Female & All & Male & Female \\
\hline Did “Organizational Image” improve? & 45.3 & 44.3 & 42.7 & 22.1 & 18.6 & 24.7 & 23.6 & 37.1 & 32.6 \\
\hline $\begin{array}{l}\text { Did “Environmental Awareness “ } \\
\text { improve? }\end{array}$ & 24.6 & 23.6 & 23.3 & 9.7 & 9.7 & 7.8 & 65.7 & 66.7 & 68.9 \\
\hline
\end{tabular}

Table 6: Occupants' assessment of organizational image and environmental awareness by gender

\begin{tabular}{|l|l|l|l|l|l|l|l|l|l|l|l|l|l|l|l|}
\hline & \multicolumn{4}{l|}{ Disagreed (\%) } & \multicolumn{4}{l|}{ Neutral (\%) } & \multicolumn{3}{l|}{ Agreed (\%) } \\
\hline & All & SM & MM & P & S & All & SM & MM & P & S & All & SM & MM & P & S \\
\hline $\begin{array}{l}\text { “Organizational Image" } \\
\text { improved }\end{array}$ & 45.3 & 53.8 & 48.4 & 39.1 & 43.3 & 22.1 & 0 & 25.8 & 21.7 & 23.9 & 23.6 & 46.2 & 25.8 & 39.2 & 32.8 \\
\hline $\begin{array}{l}\text { “Environmental } \\
\text { Awareness “improved }\end{array}$ & 24.6 & 15.4 & 15.6 & 29.2 & 22.4 & 9.7 & 0 & 15.6 & 6.3 & 7.5 & 65.7 & 84.6 & 68.8 & 64.5 & 70.1 \\
\hline
\end{tabular}

SM: Senior Manager. MM: Mid-level Manager. P: Professionals. S: Staff

Table 7: Occupants' assessment of organizational image and environmental awareness by job type

\begin{tabular}{|l|l|l|l|l|l|l|l|l|l|l|l|l|l|l|l|l|l|l|}
\hline & \multicolumn{4}{|l|}{ Disagreed (\%) } & \multicolumn{3}{l|}{ Neutral (\%) } \\
\hline & All & $\begin{array}{l}\text { Below } \\
30\end{array}$ & $31-40$ & $41-50$ & $51-60$ & $\begin{array}{l}\text { Over } \\
60\end{array}$ & All & $\begin{array}{l}\text { Below } \\
30\end{array}$ & $31-40$ & $41-50$ & $51-60$ & $\begin{array}{l}\text { Over } \\
60\end{array}$ & $\begin{array}{l}\text { All } \\
\text { Below } \\
30\end{array}$ & $\begin{array}{l}31-40 \\
41-50\end{array}$ & $\begin{array}{l}51-60 \\
\text { Over } \\
60\end{array}$ \\
\hline $\begin{array}{l}\text { Did “Organizational } \\
\text { Image" improve? }\end{array}$ & 45.3 & 15.4 & 40.6 & 43.8 & 51.7 & 42.9 & 22.1 & 38.5 & 18.8 & 25 & 19 & 14.3 & 23.6 & 46.1 & 40.6 & 31.2 & 29.3 & 42.8 \\
\hline $\begin{array}{l}\text { Did “Environmental } \\
\text { Awareness “ improve? }\end{array}$ & 24.6 & 15.4 & 20.6 & 24.5 & 24.1 & 42.9 & 9.7 & 7.7 & 8.8 & 14.3 & 5.2 & 14.3 & 65.7 & 76.9 & 70.6 & 61.2 & 70.7 & 42.8 \\
\hline
\end{tabular}

Table 8: Occupants' assessment of organizational image and environmental awareness by age group 


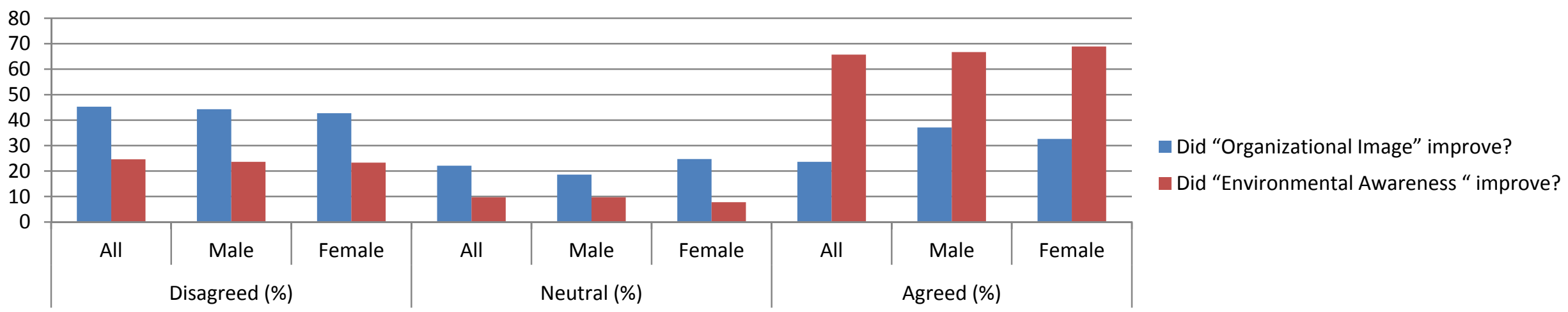

Figure 12: Occupants' assessment of organizational image and environmental awareness by gender

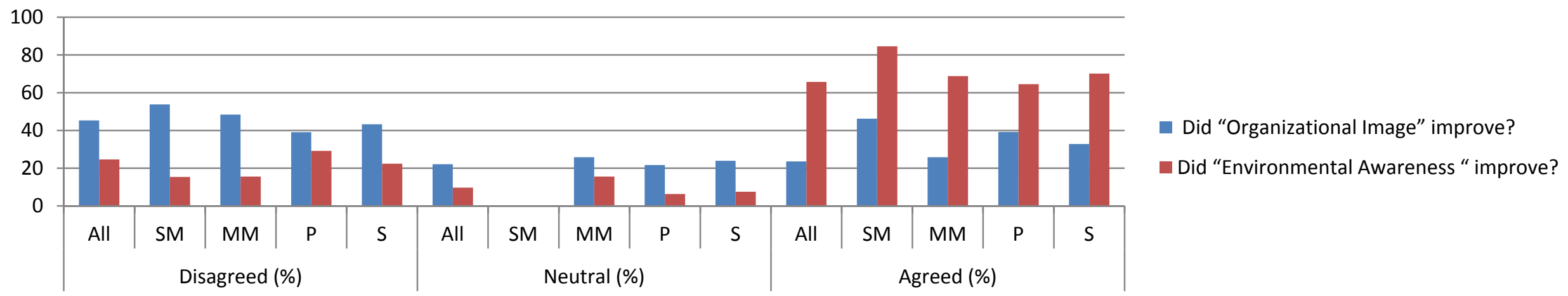

Figure13: Occupants' assessment of organizational image and environmental awareness by job type

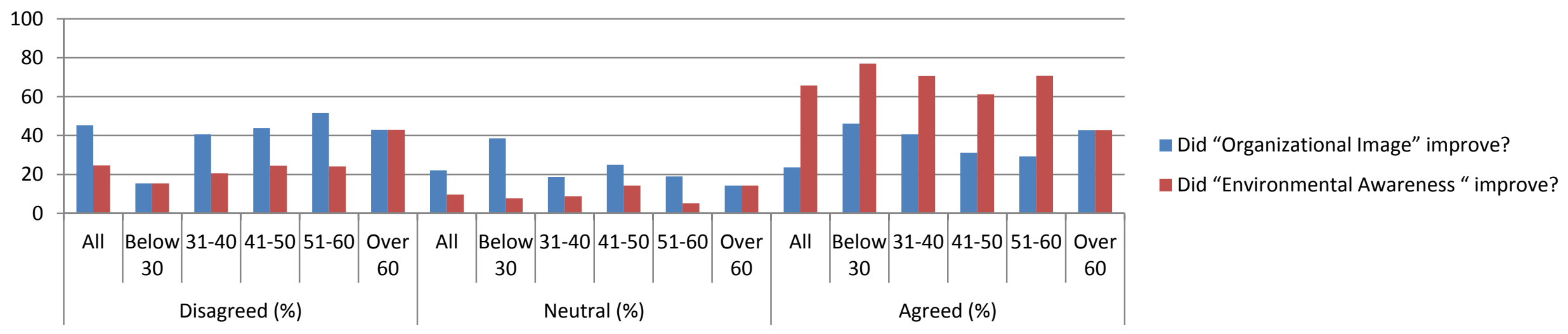

Figure 14: Occupants' assessment of organizational image and environmental awareness by age group 
significant predictor variable [Table 11]. Likewise, a regression analysis with EA as dependent variable and workspace features showing significant correlations as predictor variables also showed no significant predictor variable [Table 11].

The occupants' assessments of most departmental space features also showed significant correlation with that of EA and OI [Table 10]. However, a regression analysis with $\mathrm{OI}$ as the dependent variable and workspace features showing significant correlations as the predictor variables returned no significant predictor variable [Table 11]. However, a regression analysis with EA as the dependent variable and departmental space features showing significant correlations as the predictor variables returned only 'departmental spaces are flexible' as a significant predictor variable [Table 11].

[Insert Tables 9-11 about here]

Table 12 and Figure 15 show the frequencies of responses of the occupants' satisfaction with workspace, departmental space and the building. More than $54 \%$ of the respondents were satisfied and just over $20 \%$ were not satisfied with their individual workspaces. More than $57 \%$ of the respondents were satisfied and over $21 \%$ were not satisfied with their departmental spaces. Finally, more than $69 \%$ of the respondents were satisfied and just over $11 \%$ were not satisfied with the building.

[Insert Table 12 and Figure 15 about here]

Table 13 shows the results of the regression analysis that used the occupants' assessments of individual workspace features or departmental space features as the predictor variables and the occupants' satisfaction with workspace, departmental space and the building as the dependent variables. According to the results, the occupants' assessments of individual workspace features explained about $62 \%$ of the variation in the occupants' satisfaction with workspace; the occupants' assessments of departmental space features explained about $65 \%$ of the variation in the occupants' satisfaction with departmental space; the occupants' assessments of individual workspace features explained more than $43 \%$ of the variation in the occupants' satisfaction with the building; and the occupants' assessments of individual departmental space features explained more than $39 \%$ of the variation in the occupants' satisfaction with the building. In all the models, there were several significant predictor variables as well.

[Insert Table 13 about here] 


\begin{tabular}{|c|c|c|}
\hline & Organizational Image & Environmental Awareness \\
\hline amount of area in personal workspace fits needs & $.195^{*}$ & 0.139 \\
\hline sufficient work surfaces in workspace & $.152 *$ & 0.017 \\
\hline enough storage in workspace & $.200 * *$ & $.250 * *$ \\
\hline furniture in workspace is sufficient & $.296 * *$ & $.285^{* *}$ \\
\hline can enjoy outside view & $.174^{*}$ & 0.067 \\
\hline can adjust workspace for needs & $.303 * *$ & $.269 * *$ \\
\hline workspace helps accomplishing tasks & $.198 * *$ & $.184^{*}$ \\
\hline have enough privacy & $.275^{* *}$ & $.243^{* *}$ \\
\hline can adjust workspace to increase privacy & $.221 * *$ & $.187^{*}$ \\
\hline conversations with co-workers cannot be overheard & 0.129 & $.174^{*}$ \\
\hline phone conversations cannot be overheard & 0.107 & $.177^{*}$ \\
\hline have enough privacy to do job well & $.255^{* *}$ & $.276 * *$ \\
\hline have enough natural light in workspace & 0.111 & $.156^{*}$ \\
\hline workspace is not too bright & $.165^{*}$ & $.188^{*}$ \\
\hline lighting at desk helps job & $.323 * *$ & $.330 * *$ \\
\hline have enough fresh air in workspace & $.202 * *$ & $.240 * *$ \\
\hline happy with air quality & $.258^{* *}$ & $.273^{* *}$ \\
\hline not too hot in workspace & $.199 * *$ & $.238 * *$ \\
\hline not too cold in workspace & $.209 * *$ & $.225 * *$ \\
\hline air not too dry in workspace & $.283 * *$ & $.320 * *$ \\
\hline \multicolumn{3}{|l|}{ *. Correlation is significant at the 0.05 level (2-tailed). } \\
\hline **. Correlation is significant at the 0.01 level (2-tailed). & & \\
\hline
\end{tabular}

Table 9: Correlations between occupants' assessment of organizational image and environmental awareness with that of workspace variables 


\begin{tabular}{|c|c|c|}
\hline & Organizational Image & Environmental Awareness \\
\hline can socialize in corridors/circulation areas & $.268 * *$ & 0.128 \\
\hline can socialize in lounge/breakroom & 0.12 & 0.088 \\
\hline can socialize in coffee/snack bar & 0.129 & 0.098 \\
\hline building provides opportunities for informal conversation & $.330 * *$ & $.303 * *$ \\
\hline people I need to work with are close to my work area & $.158^{*}$ & $.181^{*}$ \\
\hline shared spaces for teamwork/impromptu meetings & $.401^{* *}$ & $.354^{* *}$ \\
\hline have no difficulty finding people needed to get work done & 0.105 & 0.07 \\
\hline can choose where I get work done in bldg. & $.186^{*}$ & $.151^{*}$ \\
\hline have easy access to equipment & $.273^{* *}$ & $.293 * *$ \\
\hline do not have to go out of way to get info from co-workers & $.250 * *$ & $.218^{* *}$ \\
\hline support equipment is convenient to workspace & $.235^{* *}$ & $.273^{* *}$ \\
\hline layout of departmental workspace supports teamwork & $.384^{* *}$ & $.415^{* *}$ \\
\hline layout of department supports impromptu meetings & $.372^{* *}$ & $.354 * *$ \\
\hline office does not lack informal meeting spaces & $.336^{* *}$ & $.269 * *$ \\
\hline conference and/or training rooms support tasks & $.233^{* *}$ & $.282 * *$ \\
\hline conference spaces available when needed & $.270^{* *}$ & $.222 * *$ \\
\hline conference spaces have suitable sizes & $.242 * *$ & $.325 * *$ \\
\hline departmental spaces are flexible & $.346^{* *}$ & $.422 * *$ \\
\hline \multicolumn{3}{|l|}{ **. Correlation is significant at the 0.01 level (2-tailed). } \\
\hline *. Correlation is significant at the 0.05 level (2-tailed). & & \\
\hline
\end{tabular}

Table 10: Correlations between occupants' assessment of organizational image and environmental awareness with that of departmental space variables 


\begin{tabular}{|c|c|c|c|c|c|c|}
\hline & & \multicolumn{3}{|c|}{ Model Summary } & \multicolumn{2}{|c|}{ ANOVA } \\
\hline & Dependent and Predictor Variables & $\mathrm{R}$ & $\begin{array}{c}\mathrm{R} \\
\text { Square }\end{array}$ & $\begin{array}{l}\text { Adjusted } \\
\text { R Square }\end{array}$ & $\mathrm{F}$ & Sig. \\
\hline Regression Model $1^{*}$ & $\begin{array}{l}\text { Dependent variable: Organization Image } \\
\text { Predictors: Individual Workspace Variables }\end{array}$ & .501 & 0.251 & 0.156 & 2.644 & .001 \\
\hline Regression Model 2* & $\begin{array}{l}\text { Dependent variable: Environmental Awareness } \\
\text { Predictors: Individual Workspace Variables }\end{array}$ & .488 & 0.238 & 0.144 & 2.519 & .001 \\
\hline Regression Model 3* & $\begin{array}{l}\text { Dependent variable: Organization Image } \\
\text { Predictors: Departmental Space Variables }\end{array}$ & .530 & 0.281 & 0.211 & 4.008 & .000 \\
\hline Regression Model 4** & $\begin{array}{l}\text { Dependent variable: Environmental Awareness } \\
\text { Predictors: Departmental Space Variables }\end{array}$ & .516 & 0.266 & 0.201 & 4.096 & .000 \\
\hline
\end{tabular}

* Regression model with no significant predictor variables

**Regression model with one significant predictor variable

Table 11: Summary of the regression models with different environmental features as the predictor variables and organizational image or environmental awareness as the dependent variable 


\begin{tabular}{|l|c|c|c|}
\hline & Disagree (\%) & Neutral (\%) & Agree (\%) \\
\hline Satisfied with workspaces & 20.1 & 25.1 & 54.8 \\
\hline Satisfied with departmental spaces & 21.6 & 21 & 57.4 \\
\hline Satisfied with the building & 11.3 & 19.2 & 69.5 \\
\hline
\end{tabular}

Table 12: Occupants' responses to satisfaction related questions 


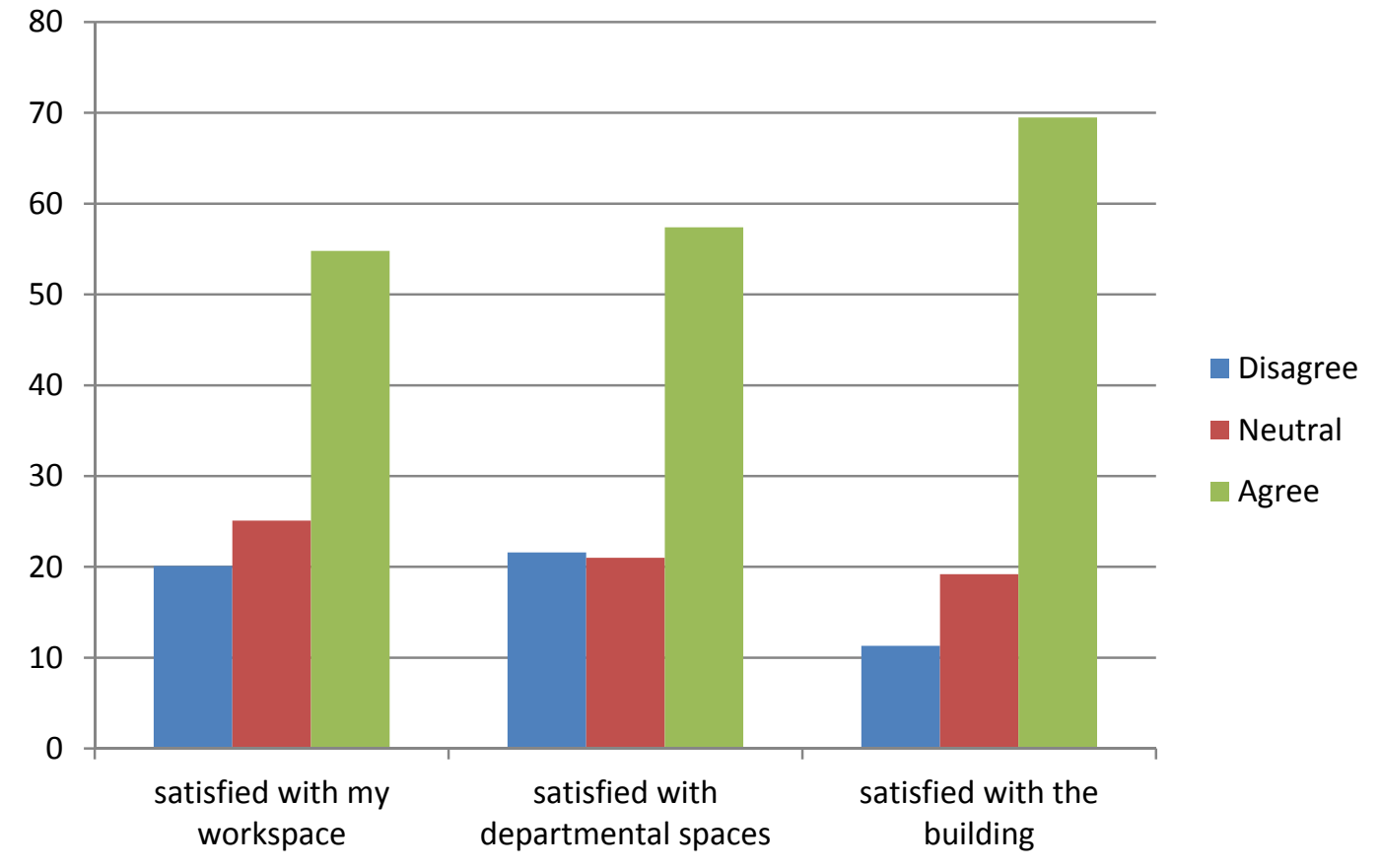

Figure 15: Occupants' responses to satisfaction related questions 
Tables 14 and 15 show the results of the regression analysis that used the occupants' satisfaction with individual workspaces, departmental spaces and the building as predictor variables and the occupants' assessments of EA and OI as dependent variables. In the regression models, 'satisfied with workspace' and 'satisfied with building' were shown as the significant predictor variables for the occupants' assessments of OI explaining about $32 \%$ of the variation in this dependent variable [Table 14], and 'satisfied with building' was shown as a significant predictor variable for the occupants' assessments of EA explaining about $29 \%$ of the variation in this dependent variable [Table 15]. However, 'satisfied with departmental spaces' was not significant in either of the two models.

[Insert Tables 14 and 15 about here]

\section{DISCUSSION}

The study showed that in general the occupants of this LEED-certified building assessed the individual workspace and departmental space features of the building favorably. However, it should be noted here that most occupants' assessed all the items related to privacy negatively in this building. This may be due to the fact that with the exception of a few enclosed individual workspaces most workspaces in the building are defined by low-height partitions. It should also be noted that regarding departmental spaces most occupants responded negatively to the question "can choose where they can get their work done". It is possible that this was an organizational issue more than a design problem.

The study also showed that the occupants agreed that this building had positive effects on EA, but not on $\mathrm{OI}$, and their assessments of EA and $\mathrm{OI}$ remained similar across gender, age, and job type. These findings are interesting in light of the fact that organizations often feel that their buildings need to be environment-friendly in order to improve organizational image. In contrast, the findings of this study suggest that the mechanisms explaining EA and OI are different in this LEED-certified 'green' building. This is in spite of the fact that the correlation between EA and OI is significantly strong $(r=0.685$, $p=0.000)$.

As the first attempt to describe the mechanisms of the occupants' assessments of EA and OI, regression models were developed with the occupants' assessments of EA and OI as the dependent variables and the occupants' assessments of workspace and departmental space features as the predictor variables. 


\begin{tabular}{|c|c|c|c|c|c|c|}
\hline & & \multicolumn{3}{|c|}{ Model Summary } & \multicolumn{2}{|c|}{ ANOVA } \\
\hline & Dependent and Predictor Variables & $\mathrm{R}$ & $\begin{array}{c}\mathrm{R} \\
\text { Square }\end{array}$ & $\begin{array}{l}\text { Adjusted } \\
\text { R Square }\end{array}$ & $\mathrm{F}$ & Sig. \\
\hline Regression Model $1 * * *$ & $\begin{array}{l}\text { Dependent variable: "satisfied with my workspace" } \\
\text { Predictors: Individual Workspace Features }\end{array}$ & 0.814 & 0.662 & 0.619 & 15.31 & .000 \\
\hline Regression Model $2 * * *$ & $\begin{array}{l}\text { Dependent variable: "satisfied with departmental spaces" } \\
\text { Predictors: Departmental Space Features }\end{array}$ & .826 & 0.682 & 0.647 & 19.418 & .000 \\
\hline Regression Model $3^{* * *}$ & $\begin{array}{l}\text { Dependent variable: "satisfied with the building" } \\
\text { Predictors: Individual Workspace Features }\end{array}$ & .705 & 0.497 & 0.431 & 7.594 & .000 \\
\hline Regression Model $4^{* * *}$ & $\begin{array}{l}\text { Dependent variable: "satisfied with the building" } \\
\text { Predictors: Departmental Space Features }\end{array}$ & 0.673 & 0.453 & 0.392 & 7.493 & .000 \\
\hline
\end{tabular}

$* * *$ Regression models with several significant predictor variables

Table 13: Summary of the regression models with environmental features as predictor variables and satisfaction as dependent variables 
Regression Model

Dependent variable: Organizational Image

Predictors: Occupants' Satisfaction

\begin{tabular}{|c|c|c|c|c|}
\hline \multicolumn{3}{|c|}{ Model Summary } & ANOVA & \\
\hline$R$ & R Square & Adjusted R Square & $F$ & Sig. \\
\hline 0.572 & 0.327 & 0.315 & 26.876 & 0 \\
\hline
\end{tabular}

\begin{tabular}{|l|c|c|}
\hline \multicolumn{2}{|c|}{ Coefficients } \\
\hline Variables & $\mathrm{t}$ & Sig. \\
\hline (Constant) & -9.453 & .000 \\
\hline satisfied with workspace & 2.635 & .009 \\
\hline satisfied with departmental spaces & .347 & .729 \\
\hline satisfied with building & 4.594 & .000 \\
\hline
\end{tabular}

Table 14: Summary of the regression model with occupants' satisfaction as predictor variables and organizational image as dependent variable 
Regression Model

Dependent variable: Environmental Awareness

Predictors: Occupants' Satisfaction

\begin{tabular}{|c|c|c|c|c|}
\hline \multicolumn{3}{|c|}{ Model Summary } & ANOVA & \\
\hline $\mathrm{R}$ & R Square & Adjusted R Square & $\mathrm{F}$ & Sig. \\
\hline 0.547 & 0.299 & 0.287 & 24.049 & 0 \\
\hline
\end{tabular}

\begin{tabular}{|l|c|c|}
\hline \multicolumn{2}{|c|}{ Coefficients } \\
\hline Variables & $\mathrm{t}$ & Sig. \\
\hline (Constant) & .786 & .433 \\
\hline satisfied with workspace & 1.624 & .106 \\
\hline satisfied with departmental spaces & .520 & .604 \\
\hline satisfied with building & 4.816 & .000 \\
\hline
\end{tabular}

Table 15: Summary of the regression model with occupants' satisfaction as predictor variables and environmental awareness as dependent variable 
Even though a large number of workspace features showed significant correlations with OI and EA, when they were used in the regression equation as the predictor variables none showed significant $F$ statistics for OI or EA. Likewise, even though a large number of departmental space features showed significant correlations with $\mathrm{Ol}$ and EA, when they were used in the regression equation as the predictor variables none showed significant $\mathrm{F}$ statistics for $\mathrm{OI}$, and only 'departmental spaces are flexible' showed significant $F$ statistics for EA (sig. = .019). These findings thus suggest that there may be no significant direct relationship between the occupants' assessments of individual workspace and departmental space features and the occupant's assessments of EA and OI.

As the second attempt to describe the mechanisms of the occupants' assessments of EA and OI, regression models were developed with the occupants' assessments of workspace and departmental space features as the predictor variables and their satisfaction with individual workspace, departmental space and the building as the dependent variables. According to the findings of these models, the occupants' assessments of individual workspace and departmental space features were the significant predictors of the occupants' satisfaction with workspace, departmental space and the building. Following this, another set of regression models that used the occupants' satisfaction with workspace, departmental space and the building as the predictor variables and the occupants' assessments of EA and $\mathrm{OI}$ as the dependent variables showed 'satisfied with building' as a significant predictor for $\mathrm{EA}$ (sig. = $.000)$, and 'satisfied with workspace' and 'satisfied with building' as the two significant predictors for OI (sig. $=.009 \& .000$, respectively). These findings thus suggest that there may be some indirect relationship between the occupants' assessments of individual work space and departmental space features and the occupant's assessments of EA and OI through the occupants' satisfaction with individual workspaces and the building. In other words, the occupants' assessments of individual workspace and departmental space features may affect the occupants' satisfaction with individual workspace and the building, which may them affect the occupants' assessments of EA and OI.

\section{CONCLUSION}

Based on the statistical analyses of the data collected from 175 occupants of a Gold-level LEED-certified building using a questionnaire instrument, this study found no evidence for direct relationships between the occupant's assessments of individual workspace and departmental space features and their 
assessments of EA and OI. The study, however, found some evidence for indirect relationships showing that the occupant's assessments of individual workspace and departmental space features had affected their satisfaction with individual workspaces and the building, which then affected the occupants' assessments of EA and OI. A summary of the study findings is provided in Figure 16.

\section{[Insert Figure 16 about here]}

Regarding the issue whether the occupants' of this LEED-certified building was "gray" or not, the findings of this study found that the occupants certainly appreciated the environmental design features of the buildings. These features had played an important role in determining how satisfied the occupants were with individual workspaces, departmental spaces, and the building. These environmental design features also made the occupants more environment-conscious, even though these features did not help improve their assessment of organizational image. In other words, even in a case where the "green" building and the organization that occupies it are treated as an integrated system with the occupants being aware of the environmental-friendliness of the building, the building may not help improve the occupants' assessment of organizational image.

In the context of heightened demands for green buildings, this study may thus offer a lesson for organizational leaders who would like to use green buildings to improve OI and/or EA. They should note that while providing "green" workspaces and buildings that satisfy occupants may help improve EA, there is no guarantee this may also help improve OI. In contrast to the suggestion made in the literature, they should further note that the mechanisms describing EA and OI could be very different in any given case with the qualification that $\mathrm{OI}$ of an organization might depend more on issues unrelated to the environmental features of a green building than EA of the organization might. In future, there will be a need to replicate this study to see if its findings hold true for other green buildings as well.

\section{REFERENCES}

Baier, R.D. (1999), “Customer service made easy: deliver what office tenants want", HPAC Engineering September, pp. 41-45. 
Adjusted R2 $=0.156^{*}$

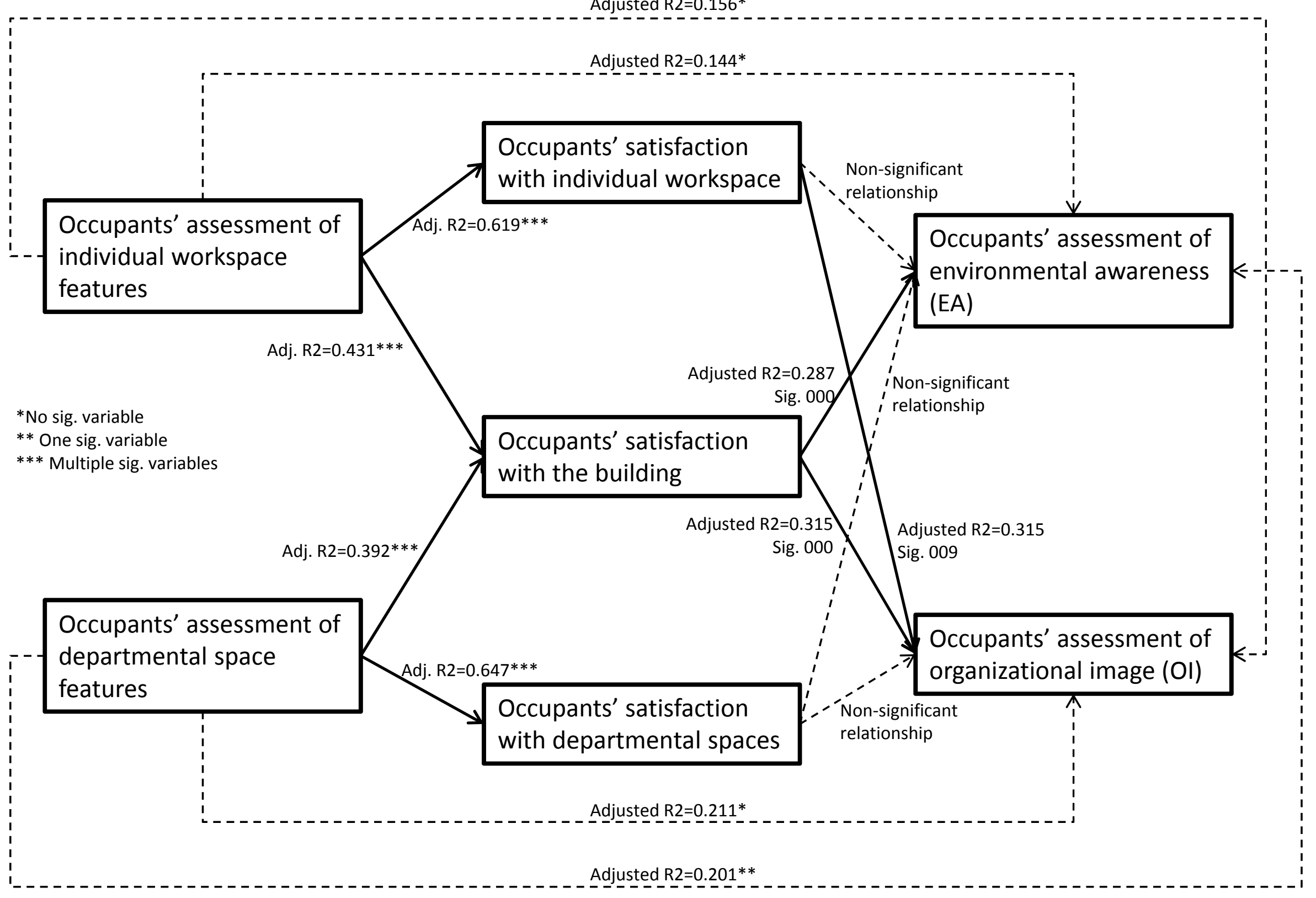

Figure 16: Summary findings 
Browning, W. and Romm, J. (1995), "Greening and the Bottom Line: Increasing Productivity through Energy Efficient Design", in Whitter, K.M. and Cohn, T.B. (Eds. ), Proceedings of the Second International Green Buildings Conference and Exposition, National Institute of Standards and Technology (NIST), Special Publications 888, Gaithersburg, MD.

Cole, R. (1999), "Green buildings and gray occupants", Paper presented the AIA-USGBC Conference on Mainstreaming Green, Chattanooga, TN, October 14-16.

EIA (2008), EIA Annual Energy Outlook 2008, (Downloaded on 07 July 2011 from

http://www.eia.gov/oiaf/archive/aeo08/ )

FMI (2008), U.S. Construction Overview 2008 (http://www.fminet.com/)

GSA PBS (2008), Assessing Green Building Performance: A Post Occupancy Evaluation of 12 GSA

Buildings, GSA Public Buildings Service, Washington, DC.

Hodgkinson, S. (1993), "Environmental Issues and the Workplace", in Duffy, F., Laing, A., and Crisp, V. (Eds.), The Responsible Workplace, Architectural Press, London, pp. 98-

Kats, G. (2003), The Costs and Financial Benefits of Green Buildings: A Report to California's Sustainable Building Task Force, October .

Makower, J. (1994), The E Factor: The Bottom Line Approach to Environmentally Responsible Business, Penguin Books, New York.

McGraw Hill Construction (2000). Green Outlook 2009: Trends Driving Change.

Miller, N., Spivey, J., Florance, A. (2007), Does Green Pay Off? (Downloaded on 07 July 2011 from http://www.costar.com/josre/pdfs/CoStar-JOSRE-Green-Study.pdf)

Rashid, M., and Zimring, C. (2008), "A Review of the Empirical Literature on the Relationships between Indoor Environment and Stress in Healthcare and Office Settings: Problems and Prospects of Sharing Evidence", Environment and Behavior, Vol. 40 No. 3, pp. 151-190.

Roodman, D.M. and Lenssen, N. (1996), “A Building Revolution: How Ecology and Health Concerns are Transforming Construction", Worldwatch Paper 124, Worldwatch Institute, March. 
US EPA (2009), Estimating 2003 Building-Related Construction and Demolition Materials Amounts, U.S. Environmental Protection Agency.

U.S. Geological Survey (2000), USGS: Data files for Estimated Use of Water in the United States 2000.

References omitted for peer review. 